\title{
Shifting orientation in Sufism: its development and doctrine adjustment in history
}

\author{
Elmansyah al-Haramain
}

Senior High School (SMA) Muhammadiyah Plus Salatiga, Indonesia E-mail: elmansyahalharamain@yahoo.co.id

\begin{abstract}
One of Islamic cultures that is constantly able to evolve and adapt to the various condition is Sufism. In the process of development, Sufism has always been a solution to various issues in society, and it is also aimed at achieving closed relation to the Lord. Shifting orientation of Sufism has occurred in any kind of its theology, politics, philosophy, and organization. The present studies of Sufism development lead to medical issues. Some experts call it Sufi Healing. It is interesting to discuss it since the shifting orientation brings something positive to the development of Sufism. However, there are many things that need to be reviewed, namely the provision of the proposition for any behavioral recovery which seemed a merely justification. This article is presented by using a historical and a phenomenological approach that emphasizes on the existence of its phenomenon. Through this article, it is expected to obtain an understanding of Sufism and its various efforts in developing the doctrine of al-ihsān in Islam in he context of digital era.

Salah satu hasil kebudayaan Islam yang senantiasa mampu berkembang dan beradaptasi secara kondisional adalah tasawuf. Dalam proses perkembangannya itu, tasawuf selalu menjadi solusi bagi pelbagai persoalan masyarakat, dan
\end{abstract}


mengarahkannya pada kedekatan diri dengan Tuhan. Pergeseran orientasi terjadi di setiap perubahan bentuk, mulai dari teologis, politis, filosofis, organisatoris. Studi tentang perkembangan tasawuf akhir-akhir ini, mulai mengarah pada persoalan medis. Para ahli menyebutnya Sufi Healing. Hal ini menarik untuk dibahas, karena pergeseran orientasi ini membawa hal positif bagi perkembangan tasawuf. Akan tetapi, ada hal yang nampaknya perlu dikaji ulang, yakni pemberian dalil atas setiap perilaku penyembuhan, yang seolah-olah merupakan justifikasi belaka. Tulisan ini disajikan dengan menggunakan pendekatan sejarah; Analisisnya menggunakan pendekatan fenomenologis. Melalui tulisan ini, diharapkan dapat diperoleh pemahaman tentang tasawuf dan berbagai upayanya dalam mengembangkan ajaran al-iḥsān dalam Islam dalam konteks era digital.

Keywords: Sufism; Sufi Healing; Orientation; History; Development

\section{Introduction}

The teachings of Islam are known to have a very broad scope. Sufism is one aspect of Islamic teachings, which instructs on how to deal directly with God. Sufism is also a branch of knowledge in Islam; scientifically it is the result of Islamic culture that was born after the Prophet's death. ${ }^{1}$ This teaching is aimed at obtaining a direct relationship with God; so in the state of conscious someone may feels the existence of the Lord. To realize these aims, he/she must run the sunna and the $w a \overline{j i b}$ in general. After that, they learn to pass the certain levels, which are known by maqāmāt, such as tawba, zuhd, tawakkal, riḍā, maḥabba, ma'rifa and intihad. ${ }^{2}$

Since its emergence, Sufism has become an interesting phenomenon. Sufism is also presented as a form of protest and against injustice done by the rulers of its time, which is left from the teachings of Islam promoted by the Prophet. The case of al-Fitna al-Kubrā that

\footnotetext{
${ }^{1}$ M. Amin Syukur, Tasawuf Sosial: Solusi Problem Manusia Modern, Yogyakarta: Pustaka Pelajar, 2004, 3.

${ }^{2}$ Tim Penyusun, Ensiklopedi Islam, Jakarta: Ichtiar Baru - Van Hoeve, 2003, 255-256.
} 
befell the Caliph Uthman ibn Affan is the result of a power struggle, which is detached from the ideals of Islam. M. Amin Syukur states this reason as one of the internal factors that cause the existence of Sufism in Islamic world. According to him, the case of al-Fitna al-Kubra on the third Caliph (Uthman ibn Affan) continued to be a civil war between Mu'awiyah and Ali ibn Abi Talib. At that time, the Ulama (Islamic Scholars) didn't want to get involved in politics, they preferred to stay in mosque to learn about targhib and tarhïb or the beauty of ascetic life. This attitude is known zuhd. ${ }^{3}$ Through Sufism, Sufis (people who practices Sufism) try to restore the awareness of Muslims in the lofty ideals of Islam itself, namely as a religion rahma li al- 'àlamin by strengthening its character.

As a religion of rahma li al- 'ālaminn, Islam has a universal and an eternal values for human is needs. This explanation can be understood based on the outline of a philosophical doctrine, i.e. aqida, shari'a, and akhlāq. ${ }^{4}$ Although the character is placed in the end of position, but the most important thing is it can be beneficial in the Islamic civilization. According to Ziauddin Sardar, normative source (author: morality) of Islam includes materialism, rationalism and mysticism in a harmonious integration. $^{5}$

Sufism, in its history has experienced so many leaps that form impressive formation. Since the ascetic movement, orders movement, up to the movement of neo-Sufism, Sufism was able to adapt, create shape and control the situations. Sufism is always placing itself as the last bastion of Muslim behavior that goes to beyond the limit. However,

${ }^{3}$ M. Amin Syukur, Menggugat Tasawuf: Sufisme dan Tanggung Jawab Sosial Abad ke-21, 2002, 29.

${ }^{4}$ Zuhairini, et al., Filsafat Pendidikan Islam, Jakarta: Bumi Aksara, 2008, 42.

5 Ziauddin Sardar, Rekayasa Peradaban Muslim, translated by Rahmani Astuti from The Future of Muslim Civilization, Bandung: Mizan, 1993, 34. 
the recent development of Sufism is relatively different. Sufism is transformed into a kind of Islamic medical system. The experts call it a Sufi Healing. Sufi healing is the combination of two words namely Sufi and healing. The word "Sufi" itself refers to the notion of one or more of the servants of God who are working or seeking others to feel peace with God. While healing is derived from the word "heal" which means healing. Therefore, the Sufi Healing can be defined as treatment with the ways of Sufism. ${ }^{6}$

The discussion has becomes interesting, because there are a lot of trials and efforts to justify the argument for the shāri'. The indication of it can be seen from the results of the Abdul Jalil's research, from the Malaya University, which discussed about the method and practice of healing using dhikr (remembrance) and du'a (benediction) in Surabaya, Indonesia; and M. Syamsul Hadi which his studies about Kiai Tabib (physician) and Traditional Healing in Surabaya7, or the result of the research from Sri Astutik, IAIN Sunan Ampel Surabaya whose research on Drug Control in Pondok Inabah Surabaya ${ }^{8}$. Abdul Jalil, Syamsul Hadi, and Sri Astutik, are talk about being lively alternative treatment done in Surabaya and surrounding areas ${ }^{9}$.

Actually, the lively alternative treatment in healing in Indonesia is not only done in Surabaya, but also in all over Indonesia. This can be seen from the tendency of people showing a television or other media con-

${ }^{6}$ M. Amin Syukur, Sufi Healing: Terapi dalam Literatur Tasawuf, Semarang: IAIN Walisongo Press, 2011, 81-83.

7 See: M. Syamsul Hadi, "Kiai Tabib dan Penyembuhan Islami: Kajian di Kota Surabaya", doctoral research, not yet finish, Surabaya: IAIN Sunan Ampel, 2011.

${ }^{8}$ See Sri Astutik, "Psikoterapi Islami dalam Mengatasi Ketergantungan Narkoba di Pon-pes Inabah Surabaya", doctoral research, unpublished, Surabaya: IAIN Sunan Ampel, 2011.

${ }^{9}$ Abdul Djalil, "Sufism: Alternative Treatment through Dhikr and Dua at Surabaya Indonesia: An Analysis from Islamic Perspective, 2005/2006", doctoral research, unpublished, Malaysia: University Malaya, 2011. 
taining the alternative treatment. We can see that, when there is a television program about alternative treatments, many viewers are interested to take apart in that program through interactive communication on telephone ${ }^{10}$.

This phenomenon indicates that there is a shift in Sufism, in term of strategy or the method of Sufism to develop schools of mysticism and faith to the Muslims in particular, and to non-Islamic people in general. This shift of strategy, in turn, will cause a shift in the orientation of the people who practice the teachings of Sufism. The extent of the shift in orientation will be revealed through this paper by unveiling the history of Sufism from the beginning to the present conditions along the history of Islamic civilization.

Therefore, this paper will be prepared systematically as follows: 1) The core teachings of Sufism; 2) The shift in the orientation of Sufism of long periods; 3) The role of Sufism in the Modern Era, and, 4) Sufi Healing as a form of shift orientation contemporary of Sufism. Through this paper, it is expected to be understood by other aspects of Islamic teachings, especially to strengthen the belief that Islam is a true religion that rahma li al- 'allamin, not a religion that should be feared as feared by the world today. The Fears of the world community became clear, after the results of the research of Samuel P. Huntington that was published in 1990s, The Clash of civilization (the West and Islam), actually occurred, as predicted by Huntington. Subsequently, it becomes negative portray of Islam, for example, Jihad as terrorism and shura and a caliphate as an anti democratic and so forth. ${ }^{11}$

\footnotetext{
${ }^{10}$ Abdul Djalil, "Sufism: Alternative Treatment through Dhikr and Dua at Surabaya Indonesia: An Analysis from Islamic Perspective, 2005/2006", 4.

${ }^{11}$ Read Samuel P. Huntington, Benturan Antarperadaban dan Masa Depan Politik Dunia (The Clash of Civilizations and the Remaking of World Order), translated by M. Sadat Ismail, Cet, 8, Yogyakarta: Penerbit Qalam, 2004.
} 


\section{Core teaching of Sufism}

Sufism is an Islamic culture that was derived from one of the Islamic teachings, namely al-ihsān. It is the doctrine of al-al-iḥsān in which person must do worship to God as he can see, and if he does not see it, then God has seen what we do. Sufism is like mysticism in general; it is also to build the deepest impulses in human beings, the impulse to realize itself as a whole as being essential and eternal nature spirituality. It does not merely esoteric, hayali (just dreamed) and odd, but rather than sublime, universal and really practical ${ }^{12}$.

To bring the deepest impulses in man, it takes practice (riyāda) and seriousness (mujāhada) in pursuing the path to God. The road to get to God is closely associated with the qualities of the heart, such as tawba, zuhd, șabr, tawāọu', taqwā, tawakkal, rị̣ā, maḥabba, and ma'rifa, and related qualities such as siddiq, ikhlāṣ, khawf, and rajā'. The scholars differ in giving the order forms of these qualities, such as Muhammad al-Kalabadzi, in his book, al-Ta'âruf li al-Madhhab Ahl alTașawwuf, said that it includes al-tawba, al-zuhd, al-șabr, al-faqr, altawāọu,' al-taqwā, al-tawakkal, al-riḍā, al-maḥabba and al-ma'rifa. Abu al-Sarraj al-Tusi, in the book al-Luma', also mentioned al-tawba, al-wira', al-zuhd, al-faqr, al-Șabr, al-tawakkal and al-riḍa. Abu Hamid al-Ghazali, in his book Ihya', explains the al-tawba, al-ṣabr, al-faqr, al-zuhd, altawakkal, al-mahabba, al-ma'rifa and al-rid̄ā. Al-Qushayri also describes al-tawba, al-wira', al-zuhd, al-șabr, and al-riḍa. But what is often referred to by scholars of șúfiya are al-tawba, al-zuhd, al-șabr, al-tawakkal and al-rid̄a. ${ }^{13}$

Maqām are what touted as the core teachings of Sufism. In addition to these qualities, there is another term that is common with the

\footnotetext{
12 M. Amin Syukur, Menggugat..., 2.

13 Abudin Nata, Akhlak Tasawuf, Jakarta: Raja Grafindo Persada, 2002, 1779.
} 
teachings of Sufism, it is ḥāl (plural: aḥwāl). Aḥwāl is a heart condition caused by the behavior of maqām (plural: maqāmāt). There are times when those qualities become things and vice versa. Regarding to maqāmāt and aḥwāl, many definitions proposed by scholars of șūfiyah, for example al-Qushayri (d. $456 \mathrm{H}$ ), interpret that maqām as an ethics $(a d a b)$, in which a slave can occupy certain levels, which will be delivered to the God with sincerity of effort. ${ }^{14}$ Thus, ahwāl is something that changes in the heart, because of dhikr.15

Definitions of various terms of the above qualities and can be delivered as follows: Tawba, tawba literally means al-rujū' min al-dhanb, ${ }^{16}$ al-rujū' 'an al-dhanb, back from sin to the goodness or away from $\sin .{ }^{17}$ Wara' is abandoning any doubtful and everything that is not useful, or leaves the goods in excess demand (fudūl). Kyai Ahmad Asrori al-Ishaqy (d. $1430 \mathrm{H}),{ }^{18}$ a Murshid Taríqa Qadiriya wa Naqshabandiya (TQN) al-Uthmāniya, the great ulama (scholar) șūfiya in Sufism of Surabaya, is quoted in the words of the Rasulullah saw., that wara' is a charity leader Who does not have properties of wara' that can prevent it from disobedience to God in his own time, and then God will not care about all his charity (H.R. Hakim and Turmuzi). Therefore, we need common sense which is controlled by a pure heart. ${ }^{19}$

Zuhd is life in ascetic. Al-Ghazali said that the overall means ascetic which is liked and hated to turn to a more preferred. ${ }^{20}$ Hamka defines

\footnotetext{
${ }^{14}$ Al-Qushayri, Al-Risālah al-Qushairiyah, Bandung: Pustaka Hidayah, 1985, 56.

${ }^{15}$ Abu Nashr as-Sarraj al-Thusi, Al-Luma', Mesir: Dār al-Kutub al-Ḥadithah, 1960, 66.

${ }^{16}$ Ibn Manzur, Lisān al-'Arab, Mishr: Dār al-Șadr, nd, 244.

${ }^{17}$ Abdul Qadir Isa, Hakekat Tasawuf, translated by publisher, Jakarta: Qisthi Press, 2005, 55.

${ }^{18}$ www.santrigresik. blogspot.com

${ }^{19}$ Achmad Asrori al-Ishaqy, al-Muntakhabat fi Rābițah al-Qalbiyyah wa Șilah al-Rūhiyyah, Surabaya: al-Khidmah, 2009, 292.

${ }^{20}$ Al-Ghazali, Iḥyā' Ulūm al-Din, translated by publisher, 1992, 207.
} 
ascetic as lā yamliku shay' wa lā yamlikuhu shay'(he/she is not having anything and not owned by anything). ${ }^{21}$

Sabr (patience) is a curb desire as a human, against a variety of consequences as a servant, so it does not come to set up with Allah. Patience is divided into three aspects: Patience li Allāh, the patient runs away from God's prohibition and do command. Patience ma'a Allāh, the patience was under qadeā' (decision) of Allah and His deeds in the form of difficulties and temptations that exist. Patience 'ala Allāh, the patience of the promises of God, whether it is related to fortune, happiness, adequacy of living, his help, and reward in the hereafter ${ }^{22}$.

Tawakkal and ridā. Tawakkal is relying on God Almighty in every respect ${ }^{23}$. While Ridla means willing. ${ }^{24}$ Mahabba is love of God..$^{25}$ Love is the turmoil that pushed to find a loved one. ${ }^{26}$ Thus, Ma'rifa is derived from 'arafa, ya'rifu, 'irfān wa ma'rifatan, which means knowledge or experience. ${ }^{27}$

While muqāraba means relying on Him alone, on peace with Him, and ask for His help. ${ }^{28}$ Ikhlās means pure, clean, and free from any purposes other than Allah. ${ }^{29}$ Khawf and raja'. Khawf means afraid, worried, or unsafe..$^{30}$ While Raja' means optimistic and never give up..$^{31}$

${ }^{21}$ Hamka, Tasawuf dan Perkembangannya, Jakarta: Pustaka Panjimas, 1993, 194.

22 Abd al-Qadir al-Jilani, al-Ghunnyah li Ṭālib Ṭarì al-Haqq, Beirut: Dār al-Fikr, na., 195.

${ }^{23}$ Amir al-Najar, Psikoterapi Sufistik dalam Kehidupan Modern, Bandung: Hikmah, 2004, 77.

${ }^{24}$ Louis Ma'luf, Al-Munjid fi al-Lughah, Beirut: Dār al-Mashriq, 1986, 265.

25 Harun Nasution, Filsafat dan Mistisisme dalam Islam, Jakarta: Bulan Bintang, 1995, 70.

${ }^{26}$ Djamaluddin Achmad al-Buny, Menelusuri Taman-Taman Mahabbah Shufiyah, Yogyakarta: Mitra Pustaka, 2002, 46-47.

27 M. Solihin and Rosihan Anwar, Kamus Tasawuf, Jakarta: Remaja Rosdakarya, 2002, 129130.

${ }^{28}$ Amir al-Najar, Psikoterapi Sufistik dalam Kehidupan Modern, 97.

${ }^{29}$ M. Solihin and Rosihan Anwar, Kamus Tasawuf, 88.

${ }^{30}$ Luwis Ma'luf, Al-Munjid fi al-Lughah, 199.

${ }^{31}$ Luwis Ma'luf, Al-Munjid fi al-Lughah, 252. 
Raja' is a firm belief about something that is loved and success in the future. ${ }^{32}$

Through this, aḥwāl and maqāmāt turn on the teachings of Sufism by making stages in Sufism. Therefore a variety of things are beneficial to the development of people, in order to get peace of soul and beauty adjacent to the Lord. Many things are introduced by the Sufis of Sufism implementation. Countless great figures appear in world of Sufism, such as al-Ghazali, Suhrawardi al-Maqtul, and Ibn Arabi.

Al-Ghazali is an author of Ihyā' 'Ulūm al-Din, a phenomenal book in Islam. His full name is Abu Hamid Mohammad ibn Mohammad alGhazali (1058-1111), known as Algazel to the western medieval world, born and died in Tus, in the Khorasan province of Persia (Now: Iran). He was a Persian Muslim theologian, jurist, philosopher, and mystic. ${ }^{33}$ Ibn 'Arabi is a Sufis from Andalusia, his full name is Muhammad ibn Ali ibn Ahmad ibn al-Abdullah al-Hitami al-Tha'i al-'Arabi. He was born in Murcia, Spain in $560 \mathrm{H}$. He was a famous with his concept of al-wihda al-wujūd, ${ }^{34}$ a philosopher peripatetic, who was able to express their religious experience to a metaphysical view. ${ }^{35}$ Suhrawardi al-Maqtul is a Shahab ad-Din Yahya ibn Habash as-Suhrawardi is also known as Sohrevardi. He was a Persian philosopher, a Sufi and a founder of the illuminationist philosophy or "Oriental Theosophy", an important school in Islamic mysticism that drew upon Zoroastrian and Platonic ideas. The "Orient" of his "Oriental Theosophy" symbolizes spiritual light and knowledge. He was sometimes given the honorific title as Shaykh alIshraq or "Master of Illumination" and sometimes was called Shaykh

\footnotetext{
32 Al-Qusyairy, Al-Risālah al-Qushairiyah, 132.

33 http://en.wikipedia.org/wiki/Al-Ghazali

34 M. Solihin and Rosihan Anwar, Kamus Tasawuf, 81-82.

35 Franz Rosenthal, The Classical Heritage in Islam, New York: Routledge, 1998, 35.
} 
al-Maqtul, the "Murdered Sheikh", referring to his execution for heresy. ${ }^{36}$ They are the great figures of his day and still resonate today.

\section{Orientations of Sufism}

Sufism has gone through a very long time, along with the history of Islam itself. From the root word of Sufism, it is taken from the word ahl al-Suffa, where they were companions of the Prophet who dwells in Nabawi mosque. The Prophet cherished them, even He issued a statement of the Prophet: "Whoever heard of people of Sufism ( $\mathrm{Ahl}$ alSuffa) pray, but not say "Amen" for their praying, it was written on the side of God as someone who fails". ${ }^{37}$

However, if we analyzed the root of its presence in Islamic history, namely at the period of Șahaba, it is clear that Sufism has a theological and political orientations. Theological orientation here is interpreted as an act to deepen the faith of the Islamic 'aqìda of the ihsān, while political orientation is interpreted as a form of protest to against the evils of government and politics in its time.

Judging from its development since the Tașawwuf Sunnï, Taṣawwuf Falsafi, tarekat, to the neo-Sufism, Sufism in these times seems more adaptable to the development of the surrounding environment. Sufism was always motivated by contextual metamorphosis of the meaning of zuhd by each generation according to socio-political constellation in each order of the history of Islamic civilization, it was in the classical period (650-1250 AD), medieval period (1250-1800) and modern period (1800-present).

Classical period and the medieval period is a period that is a vital for growth and development of Sufism. It is said that, in this period, Sufism

\footnotetext{
36 http://en.wikipedia.org/wiki/Shahab_al-Din_Suhrawardi

${ }^{37}$ Al -Hujwiri, Kashf al-Mahjūb: Risalah Persia Tertua tentang Tasawuf, translated by Suwardjo Muthary and Abdul Hadi W.M., Bandung: Mizan, 1997, 227.
} 
has managed to find a basic epistemology, so that Sufism is able to establish itself as one of the sub-disciplines within Islamic civilization. As the result, we can see from the construction of mysticism itself. It is broadly classified into three namely akhlāqì, 'amali, and falsafi Sufism. ${ }^{38}$ Here is an explanation of those three things.

Firstly moral Sufism (tașawwuf akhlāqì). The main focus of aașawwuf akhlāqi (akhlāqỉ Sufism) course is more oriented on the level of "morality". In the Introduction of Mysticism of IAIN North Sumatra, which was written by Abu Bakkar Atjeh, explained that tașawwuf akhlāqi tells more about the perfection and sanctity of life that are formulated toward mental attitudes and behavior of strict discipline. In order to achieve optimal happiness, in this context, someone have to identified the existence of him/herself with the characteristics of divinity through purification of soul and body, which stems from the formation of a moral person plenary, and have a certain character, who is in mysticism known as takhālli (self-emptying of despicable traits), tahalli (adorn yourself with admirable traits), and tajalli (Nūr Ghālib) revelations to the soul that has been clean to capture the divine light). ${ }^{39}$

Secondly, applied Sufism (tașawwuf 'amali). It also explains that the main focus in tașawwuf 'amali is departing from the question on how to draw closer to God. In this context, tașawwuf 'amali is connoted by tarekat (Sufi orders). Tarekat (order) is the ability to distinguish between the Sufi and others. There are people who are considered capable to know how to draw closer to God, and there are people who need help from others who are considered to have authority in the matter. In subsequent developments, the seeker and a lot of followers

\footnotetext{
38 See Danusiri, Epistemologi dalam Tasawuf Iqbal, Yogyakarta: Pustaka Pelajar, 1996.

39 M. Amin Syukur, Menggugat Tasawuf: Sufisme dan Tanggung Jawab Sosial Abad ke-21, $2002,45$.
} 
grew and formed a kind of social community of like-minded, and it increased the strata based on the knowledge and practice they do. Furthermore, in terms of disciple, murshïd, murid, and wali guardians began to be known. ${ }^{40} \mathrm{M}$. Amin Syukur is uniting between Sufism Science, tașawwuf akhlāqi and tașawwuf 'amali in one term that is applied in mysticism. According to him, applied Sufism is not only a theory, but also it requires practice in order to achieve the goals of Sufism. People who run Sufism will find balance in life, between material and spiritual world. ${ }^{41}$

Thirdly philosophicar Sufism (tașawwuf falsafi). According to alTaftazani in Madkhal Ilā al-Tașawwuf al-Islāmì, that Sufism is the philosophical teachings that combine the intuitive vision and rational vision. The terminology used comes from a variety of teachings in philosophy that has influenced the characters, but his originality as Sufism is still not lost although this philosophical Sufism cannot be viewed as a philosophy, because the teachings and methods are based on taste (dhawq), it can't be categorized purely in Sufism (the pure) because it is often expressed in language of philosophy. ${ }^{42}$

The consensus among such scholars of Sufism cannot be separated from the role of the great Islamic civilization of classical and medieval periods that have been in such a way to do contextual meaning of ascetic Sufism as an embryo. Consequently, zuhd is not only conceptual and operational at this time. It has undergone a series of historical processes which the author himself termed metamorphosiscrystallize. Metamorphosis-crystallize are combination of two English

${ }^{40}$ M. Amin Syukur, Menggugat Tasawuf, p. 50.

${ }^{41}$ M. Amin Syukur and Masyharudin, Intelektualisme Tasawuf, Yogyakarta: Pustaka Pelajar, $2002,43$.

${ }^{42}$ M. Amin Syukur and Masyharudin, Intelektualisme Tasawuf, 51. 
words. Metamorphosis means change of form, while the meaning of crystallize in reality is to obtain a clear form. ${ }^{43}$

Meanwhile there are more extreme groups in expressing all their zuhd. This group in the study of Sufism often referred to a school of Kufah (due to the city of Kufah) and the school of Basrah (as centered in the city of Basrah). The flow of Kufah, figured by Sufyan alTsauri (W.135H), Abu Hashim $(150 \mathrm{H})$ and Jabir Ibn Hashim $(190 \mathrm{H})$. The Zahid Kufa was the one who the first time wearing coarse woolen cloth as a form of protest against the silk fabric, at that time it became a symbol of luxury. Meanwhile, the school of Basra was more extreme by taking up the ascetic style to the mystical teachings of main character to Hasan al-Basri $(110 \mathrm{H})$ and Rabi'a al-'Adawiyah $(185 \mathrm{H})$. From these two cities, ascetic is conceptual or practical and it is spread to other areas, such as in Khorasan (Persian). It appears the name of Ibrahim ibn Adnan (762 M) with his student Syafiq al-Balkhi (194 M); Medina appears Ja'far al-Saddiq (148 M) ${ }^{44}$

Hasan al-Basri began to introduce the understanding of Sufism called khawf wa raja' (fear and hope). The direction of this concept can be classified into twofold: (1) Focusing on the worship of God (because there was worry that the worship is not accepted by Allah swt. and (2) not focusing to the world and material or physical matters and that can grow attitudes of ascetic. Ascetic attitude here is defined as leaving the world and material and physical matters. Hasan al-Basri adds that this can be regarded as conceptual foundation of the ascetic life. The concept of khawf wa raja' is increasingly strong after Rabi'ah al-Adawiyah laying mahabba as a basic concepts of love to God asking nothing in

43 John Echols and Hassan Shadily, Kamus Inggris-Indonesia, Jakarta: PT. Gramedia, 1992, 58 and 379.

${ }^{44}$ Harun Nasution, Filsafat dan Mistisime dalam Islam, Jakarta: PT. Gramedia, 1995, 65-66. 
return. The attitudes of asceticism after passing mahabba concept were becoming increasingly peaked, especially if coupled with a real attitudes in the form of rough wool dress as a symbol. Thus it can be said that the ascetic life was growing stronger especially when the school of Kufah expressed it in the symbol of the coarse woolen garments, and the school of Basra who conceived with khawf wa raja'and mahabba. 45

Based on the above data, it is not excessive if the authors conclude that in VII and VIII centuries AD, it become the first phase of metamorphosis ascetic in the tradition of Sufism. The first phase of this has been a sort of transition from the ascetic practices that is practically emphasized on the moral aspect to seed the ascetic concept (theoretical-philosophical), although in a small scale. Thus, in the view of this history, it cannot be explicitly distinguished between practice and philosophy. This kind of Sufism pattern can be regarded as taqlidi Sufism. ${ }^{46}$

When Taqlidiya phase was in IX and XII centuries $A D$, it was faced with a condition in which there has been a massive penetration of the philosophical tradition into the Islamic community at the time of the Abbasid Caliphate's rule. Through the legacy of Sufism philosophical sufism, here are some figures seem to be truly inspired to develop the source of the philosophical orientation of the ascetic teachings of Hasan al-Basri and Rabi'ah al-Adawiyah. They created new forms of ascetic orientation that was a philosophical orientation which gave birth to philosophical Sufism. Dzun Nun al-Misri, for example, was the Hellenistic scholar of Islamic tradition. ${ }^{47}$ Also during this period it also created

45 Mohammad Damami, Tasawuf Positif dalam Pemikiran Hamka, Yogyakarta: Fajar Pustaka, 2000, 160.

${ }^{46}$ Amin Syukur, Zuhd di Abad Modern, Yogyakarta: Pustaka Pelajar, 2000, 14.

47 Reynolds A. Nicholson, The Mystics of Islam, New York, 1975, 18; Hamka, Tasawuf Modern, Jakarta: Bulan Bintang, 1994, 91. 
famous names such as Abu Yazid al-Bustami (d. $861 \mathrm{M}$ ) with his teaching, fana'. After Abu Yazid, was born a famous Sufi, al-Hallaj namely through ḥulūl theory, Nūr Muḥammad and al-Waḥda al-Adyān. At this time, Junaidi Al-Baghdadi has laid the foundation for the growth and development of tarekat (orders). ${ }^{48}$

Beyond the philosophical mysticism network above, it comes to the group who considered that the philosophical Sufism has excessive understanding of zuhd or ascetic. The group then binds itself as a school of Sunni Sufism (Tașawwuf Sunnī) which seeks its teaching from the al-Quran and Sunna. At this time, both philosophical and Sunni Sufism were involved in a great intellectual contest. Sunni Sufism emerged in victory with al-Qushayri, al-Harawi and al-Ghazali as the main masters. ${ }^{49}$

It is understandable that in IX and XII century AD, ascetic experience is a second phase of metamorphosis. Atjeh was inspired by Abu Bakr, the authors named this as a phase of Madhhabiya. This phase continued until the end of XIII century. At that time, this has happened where the victory alternated between Sunni Sufism or Falsafi Sufism. If the philosophical Sufism in the eleventh century was changed by Sunni Sufism, it would turn to the twelfth century where philosophical mysticism of Sunni Sufism replaced the victory, and then Suhrawardi50 and Ibn 'Araby come to be well known. ${ }^{51}$

Both Sunni and intellectual contest have given a rise to philosophical divisions within Islam and Sufism itself, and they also have become instrument of strengthening the building of scientific mysticism. From the point of the philosopical mysticism, 'Amali has combined science

${ }^{48}$ M. Amin Syukur and Masyharudin, Intelektualisme Tasawuf, 24.

49 M. Amin Syukur and Masyharudin, Intelektualisme Tasawuf, 25

${ }^{50}$ Read Hossein Ziai, Suhrawardi dan Filsafat Illuminasi: Pencerahan Ilmu Pengetahuan, translated by Afif Muhammad and Muniru Zaman, Bandung: Wacana Mulia, 1998, 11.

${ }^{51}$ See Franz Rosenthal, The Classical Heritage in Islam, New York: Routledge, 1998, 35. 
and philosophical mysticism. Meanwhile, Sunni Sufism has become the basis of Akhlāqi. So it can be concluded that metamorphosis of asceticism that has gone through phases including of taqlidiya madhhabiya has played a major role in the scientific basis of Sufism. Philosophical Sufism could be the basis of epistemology, Akhlāqi Sufism is the ontological basis, and Sufism is a basis of 'Amali axiologi.

Along with the times, Sufism continued to grow. After Sufism developed its emotion, spirituality, and intellectualism in the Islamic world throughout the 12th century and the 13th AD, Ahl al-Hadith felt that Sufism is irreversible. The group of scholars who have sense of responsibility towards Sufi Revivalism was Ahl al-Hadith (traditionist). Resurgence of Sufism was called, by Fazlurrahman as "Neo-Sufism".52 According to Fazlurrahman, Neo-Sufism is a mysticism that has been revitalized and mainly stripped by features and content of asceticism and metaphysics, and it was supported by the arguments of Islamic orthodoxy. This model emphasizes on moral factor and self-control at the expense of excessive characteristic of popular Sufism (heterodox Sufism). The focus of neo-Sufism is a socio-moral reconstruction of Muslim society. This is very different from previous Sufism, which only emphasizes on the individual but not society. ${ }^{53}$

It seems clear that Sufism has always metamorphosed in accordance with its circumstances. In addition, the orientation has always adapted situation demands. However, the history shows that Sufism has never been separated from moral orientation. The shift continues to return Sufism to the true teachings of Islam, al-Quran and al-Sunna.

52 Fazlurrahman, Islam, Chicago: University of Chicago Press, 1979, 195.

${ }^{53}$ Azyumardi Azra, Jaringan Ulama Timur Tengah dan Kepulauan Nusantara Abad XVII dan XVIII, Bandung: Mizan, 1998, 110. 
Today, along with the proliferation of traditional or alternative medicine, whether Islamic or not, this motivated the researchers to examine its tendency deeply. Some researches indicated that most of these alternative treatments were referred to the Sufi behavior. The experts call it as Sufism healing. The question is whether this is also one form of orientation shifts in Sufism. The following description will explain this new phenomenon.

\section{Sufi healing}

Before discussing more about this phenomenon of Sufi healing, it is necessary for us to understand the circumstances of contemporary Sufism. This will be the starting point for shifting orientation in Sufism. Therefore, it is believed that any changes that occur in Sufism is a form of response to its environment.

Whether it is recognized or not, at this time we have entered into the digital world, which makes alpha-numeric numbers as the basis for development. It is said that the binary numbers ( 0 and 1$)$ are used by the technologist in creating various forms of advanced technology. It is the basic teachings of monotheism in Islam. Zero and One, is the epitome of the phrase Là ilāha Illa Allāh, Lā Ilāha (0) Illa Allāh (1). In the development of science and technology, these numbers has created electric technology and computerization of all-powerful machines. ${ }^{54}$

Development of science and technology today's digital era, helps the human work in one side, and the other side, it creates a change in attitudes and behavior. Unfortunately, there are manythings changing into negative attitudes and behaviors in the community of the world. M. Amin explains in detail about these negative changes. He divided it

\footnotetext{
${ }^{54}$ Read Ari Ginajar Agustian, ESQ Power: Sebuah Inner Journey Menuju Al-Ihsan, Jakarta: Arga, 2003; M. Amin Syukur, Sufi Healing.
} 
into four types, namely: the erosion of cultural values that lead to moral degradation, the rise of liberalism that glorifies freedom without limits, the development of rational ideology that rejects the spiritual existence, and the development of materialistic way of life that leads to the hedonistic ideology. ${ }^{55}$

Furthermore, the change of attitudes and behaviors turned to the result of the growth of various forms of strange diseases in the community, in which almost all of them are caused by depressed mind. Therefore, the scholars of șuffiya in this era have been regarded as the solution of the problem. Psychological roots of Sufism in Islam are drawn into psychotherapy. The result is amazing because a lot of people seek this treatment, and they declared that it really works!

Looking at the phenomenon of this treatment, many people want to know more about scientific studies. Some researchers are trying to take more time to analyze; even many academics make it as the object of research materials. Some dissertations are interested to mention, with regarding this issue; dissertation done by Siti Nur Asiyah ${ }^{56}$, Sri Astutik, ${ }^{57}$ Abdul Jalil,, ${ }^{58}$ Syamsul Hadi, ${ }^{59}$ Khasrusuddin Aqib, ${ }^{60} \mathrm{M}$. Shaleh, ${ }^{61}$ etc.

${ }^{55}$ M. Amin Syukur, Sufi Healing, 27-38.

${ }^{56}$ Siti Nur Asiyah, "Peningkatan Imunitas pada Peserta Majelis Dhikr", doctoral research, unpublished, Surabaya: University or Airlangga, 2010, 96.

${ }^{57}$ Sri Astutik, "Psikoterapi Islami dalam Mengatasi Ketergantungan Narkoba di Pon-pes Inabah Surabaya", doctoral research, unpublished, Surabaya: IAIN Sunan Ampel, 2011.

${ }^{58}$ Abdul Jalil, "Metode dan Amalan Perubatan Alternatif Menggunakan Zikir dan Dua: Kajian Khusus Di Kota Surabaya, Indonesia", doctoral thesis, University Malaya, Malaysia, 2011.

${ }^{59}$ M. Syamsul Hadi, Kiai.

${ }^{60}$ Kharisuddin Aqib, "Tarekat Qadiriyah wa Nahsyabandiyah Suryalaya: Studi Tentang Tazkiyatun Nafs Sebagai Metode Penyadaran Diri", doctoral research, Jakarta: UIN Syarif Hidayatullah, 2001.

${ }^{61}$ Muh. Soleh, "Pengaruh Sholat Tahajud terhadap Respons Ketahanan Tubuh", doctoral research, Surabaya: PPs Unair, 2000. 
Siti Nur Asiyah, has studied a dhikir group (Majelis Taklim Miftahul Jannah) at Pondok Pesantren (Islamic boarding school) Darussalam Gadung, Driyorejo, Gresik, East Java. She has discovered new things, namely the occurrence of elevated levels of eHSP 72 followed by a trend of increased levels of IL-IB, IL-6 and NK cell to new participants after attending dhikr activities. It means that $d u^{\prime} \mathbf{a}^{\prime}, d h i k r$ and tawșiya received by the participants in the Majelis Taklim are potential to enhance immunity. ${ }^{62}$

This study really relates to the values of Sufism, in which $d h i k r, d u^{\prime} \bar{a}^{\prime}$ (prayer), șalāwāt (blessings on the Prophet Muhammad), șalā (prayer), and listening music (especially Sufi's music) are preferred medium in order to get closer to God. These things can be used as the ways of healing, Sufi Healing.63

Sri Astutik's research on the methods of Islamic healing in Pondok Inabah Surabaya finds out that the process of theraphy in PPIS (Pondok Pesantren Inabah Surabaya), used to utiliz belief system theory through the techniques of Spiritual Behavior of Emotive Rational Therapy (SBERTherapy). Thus, both therapy and personal approach are proclaimed in the process of coaching and healing victims of drug abuse. In this case the therapy needs some practices such as; tawba's bath,talqin, du'ā', dhikr, qiyām al-layl, șalā, fasting, and akhlāq al-karimah. ${ }^{64}$

It is almost the same with the studies conducted by Abdul Djalil, Khasriruddin Aqib, Syamsul Hadi, and Muh. Soleh, all of them are using the same assumptions, i.e. dhikr lead to inner peace and happiness, and that peace and happiness can affect physical health. In the theory of health, this is known as psycho-neuro-endocrine-immunology. ${ }^{65}$

\footnotetext{
62 Siti Nur Asiyah, Pengajian..., 96.

63 M. Amin Syukur, Sufi Healing...., 115-116.

64 Sri Astutik, Psikoterapi..., 194-195.

65 M. Amin Syukur, Sufi Healing...., 109.
} 
These studies show that the therapy treatment is more influenced by the teachings of Sufism. Although it is not specifically mentioned, but the fact that it was done through the ways of treatment of Sufism, it is also more common in the terms and practices of Sufism. Mostly, the Islamic alternative treatment system is relying on dhikr, and good deeds. It is also recognized by In'amuzahidin in his dissertation research the practices of the Sufism in fact contain a system of medicine. He focused on remembrance as the core of diagnostics and therapy. This is done by the Sufi healers in treatment practices. Dhikr itself is the most important element in the practice of Sufism, in addition to reducing the food and drink consumption, and khalwa, are also the means of purifying the heart. ${ }^{66}$

We need a study of phenomena in which Sufi's therapy preferred by some people than modern medicine. Some of them argue that they want to seek Islamic therapy, which partly justified because modern medicine is no longer able to cope with their illness. In addition, there is also an argument that the traditional therapy is cheaper than modern one.

In any level, this fact will certainly shift Muslim's orientation of entering Sufism although it remains to strengthen Sufi's moral orientation both in its fundamentals and practices.

\section{Conclusion}

There are three main things could be inferred from this brief article, namely: Sufism is initially a moral doctrine that emphasizes on three domains of God, nature and moral characters. Then, these three characters has shifted into the doctrine of divinity, which is aimed at

66 Muh. In'amuzahidin, "Mukasyafah dalam Tasawuf: Studi Pemikiran Mukasyafah Ibn Atha'illah al-Sakandari", doctoral research, Jakarta: UIN Syarif Hidayatullah, 2010, 128. 
directing human beings in closed relation to their God. From here, it will evolve in the field of science on how to deal directly with God. Furthermore, the shift continues to occur in accordance with the development of community.

The recent development indicates shifting orientation that leads to medical issues. Sufi Healing is one of shifting orientation although it was merely a method to strengthen Sufism in today's digital world. It seems that the shift of orientation in Sufism is undergone by the patient, not about the Sufis or Sufism itself. The teachings of sufism also run in corridor of mainstream of Sufism.

\section{Bibliography}

Agustian, Ari Ginanjar. ESQ Power: Sebuah Inner Journey Menuju Alihsan. Jakarta: Arga, 2003.

Aqib, Khasrisuddin, "Tarekat Qadiriyah wa Nahsyabandiyah Suryalaya: Studi tentang Tazkiyatun Nafs sebagai Metode Penyadaran Diri", doctoral research, Jakarta: UIN Syarif Hidayatullah, 2001.

Asiyah, Siti Nur. Pengajian dapat Menghasilkan Imunitas Tinggi. Surabaya: Universitas Airlangga, 2010.

Astutik, Sri, "Psikoterapi Islami dalam Mengatasi Ketergantungan Narkoba di Ponpes Inabah Surabaya", doctoral research, Surabaya: IAIN Sunan Ampel, 2011.

Astutik, Sri, "Psikoterapi Islami dalam Mengatasi Ketergantungan Narkoba di Pon-pes Inabah Surabaya", dissertation, Surabaya: IAIN Sunan Ampel, Surabaya, 2011.

Azra, Azyumardi. Jaringan Ulama Timur Tengah dan Kepulauan Nusantara Abad XVII dan XVIII. Bandung: Mizan, 1998.

Al-Buny, Djamaluddin Achmad. Menelusuri Taman-Taman Mah\}abba Shufiyah. Yogyakarta: Mitra Pustaka, 2002. 
Burhani, Ahmad Najib. Tarekat Tanpa Tarekat, Jalan Baru Menuju Sufi. Yogyakarta: Serambi Ilmu Semesta, 2002.

Damami, Mohammad. Tasawuf Positif dalam Pemikiran Hamka. Yogyakarta: Fajar Pustaka, 2000.

Danusiri. Epistemologi dalam Tasawuf Iqbal. Yogyakarta: Pustaka Pelajar, 1996.

Dhahir, Ihsan Ilahi. Sejarah Hitam Tasawuf: Latar Belakang Kesesatan Kaum Sufi. Jakarta: Dar al-Falah, 2001.

Djalil, Abdul, "Metode dan Amalan Perubatan Alternatif Menggunakan Zikir dan Dua: Kajian Khusus Di Kota Surabaya, Indonesia", doctoral thesis, University Malaya, Malaysia, 2011.

Djalil, Abdul, "Sufism: Alternative Treatment Through Dhikr and Dua at Surabaya Indonesia: An Analysis from Islamic Perspective, 2005/ 2006", doctoral research, Malaysia: University Malaya, 2011.

Echols, John and Shadily, Hassan. Kamus Inggris-Indonesia. Jakarta: PT. Gramedia, 1992.

Fazlurrahman. Islam. Chicago: University of Chicago Press, 1979. Al-Ghazali. Ihyyā' 'Ulūm al-Dìn. 1992.

Hadi, M. Syamsul, "Kiai Tabib dan Penyembuhan Islami: Kajian di Kota Surabaya", site plan for doctoral research, Surabaya: IAIN Sunan Ampel, 2011.

Hamka. Tasawuf dan Perkembangannya. Jakarta: Pustaka Panjimas, 1993. http://en.wikipedia.org/wiki/Al-Ghazali

http://en.wikipedia.org/wiki/Shahab_al-Din_Suhrawardi

Al-Hujwiri. Kash al-Mahjūb: Risalah Persia Tertua tentang Tasawuf. translated by Suwardjo Muthary and Abdul Hadi W.M. Bandung: Mizan, 1997. 
Huntington, Samuel P. Benturan Antarperadaban dan Masa Depan Politik Dunia. translated by M. Sadat Ismail. Yogyakarta: Penerbit Qalam, 2004.

In'amuzahidin, Muh, "Mukasyafah dalam Tasawuf: Studi Pemikiran Mukasyafah Ibn Atha'illah al-Sakandari", doctoral research, unpublished, Jakarta: UIN Syarif Hidayatullah, 2010.

Isa, Abdul Qadir. Hakekat Tasawuf. Jakarta: Qisthi Press, 2005.

Al-Ishaqy, Achmad Asrori. Al-Muntakhabat fi Rābitah al-Qalbiyyah wa Șilah al-Rūhiyyah. Subaya: al-Khidmah, 2009.

Al-Jilani, Abd al-Qadir. al-Ghunnyah li Ṭālib Ṭarīq al-Haqq. Beirut: Dar alFikr, na.

Ma'luf, Louis. Al-Munjid fi al-Lughah. Beirut: Dār al-Mashriq, 1986.

Manzur, Ibn. Lisān al-'Arab. Mishr: Dār al-Șadr, na.

Al-Najar, Amir. Psikoterapi Sufistik dalam Kehidupan Modern. Bandung: Hikmah, 2004.

Nasution, Harun. Filsafat dan Mistisisme dalam Islam. Jakarta: PT. Gramedia, 1995.

Nata, Abudin. Akhlak Tasawuf. Jakarta: Raja Grafindo Persada, 2002. Nicholson, R.A. The Mystics of Islam. New York, 1975.

Al-Qushayri. Al-Risālah al-Qushairiyah. Bandung: Pustaka Hidayah, 1985. Rosenthal, Franz. The Classical Heritage in Islam. New York: Routledge, 1998.

Sardar, Ziauddin. Rekayasa Peradaban Muslim. translated by Rahmani Astuti. Bandung: Mizan,1993.

Siregar, Rivay. Tasawuf : dari Sufisme Klasik ke Neo-Sufisme. Jakarta: Rajawali Press, 2000. 
Soleh, Muh, "Pengaruh Sholat Tahajud terhadap Respons Ketahanan Tubuh", doctoral research, Surabaya: PPs Unair, 2000.

Solihin, M. and Anwar, Rosihan. Kamus Tasawuf. Jakarta: Remaja Rosdakarya, 2002.

Syukur, M. Amin and Masyharudin. Intelektualisme Tasawuf. Yogyakarta: Pustaka Pelajar, 2002.

Syukur, M. Amin. Menggugat Tasawwuf: Sufisme dan Tanggung Jawab Sosial Abad ke-21, 2002.

Syukur, M. Amin. Sufi Healing: Terapi dalam Literatur Tasawuf. Semarang: IAIN Walisongo Press, 2011.

Syukur, M. Amin. Tasawuf Sosial: Solusi Problem Manusia Modern. Yogyakarta: Pustaka Pelajar, 2004.

Syukur, M. Amin. Zuhd di Abad Modern. Yogyakarta: Pustaka Pelajar, 2000.

Al-Thusi, Abu Nashr al-Sarraj. Al-Luma'. Mesir: Dār al-Kutub al-Ḥadithah, 1960.

Tim Penyusun. Ensiklopedi Islam. Jakarta: Ichtiar Baru-van Hoeve, 2003.

www.santrigresik. blogspot.com.

Ziai, Hossein. Suhrawardi dan Filsafat Illuminasi: Pencerahan Ilmu Pengetahun. translated by Afif Muhammad and Muniru Zaman. Bandung: Wacana Mulia, 1998.

Zuhairini, et al. Filsafat Pendidikan Islam. Jakarta: Bumi Aksara, 2008. 